Герасимчук В.Г. доктор економ. наук, професор ORCID ID: 0000-0003-0674-1814

Начіональний технічний університет Украйни "Київський політехнічний інститут імені Ігоря Сікорського"

\title{
КРАЇНИ БАЛКАНСЬКОГО РЕГІОНУ В СТРУКТУРІ ЗОВНІШНЬОЇ ТОРГІВЛІ УКРАЇНИ
}

\section{СТРАНЫ БАЛКАНСКОГО РЕГИОНА В СТРУКТУРЕ ВНЕШНЕЙ ТОРГОВЛИ УКРАИНЫ}

\section{COUNTRIES OF BALKAN REGION ARE IN PATTERN OF TRADE OF UKRAINE}

Розглянуто фактори впливу на розширення торговельно-економічного співробітництва України з балканськими державами. Зовнішньоекономічні зв'язки оцінюються як з позииій розширення присутності України на ринку Балканського регіону, так із позицій стратегічних намірів - посилення ї̈ впливу на ринку ЄС. Здійснено порівняльний аналіз стану соџіально-економічного розвитку Украйни та балканських держав за основними показниками. Наведено групи показників та місие Украӥни, кожної 3 балканських держав в Індексі процвітання країн (економіка, підприємництво, державне управління, освіта, охорона здоров'я, безпека, особисті свободи, сочіальний капітал). Досліджено тенденції здійснення експортно-імпортних операцій між Украйною та балканськими країнами. Запропоновано рекомендачії щуодо подальмого розвитку двосторонніх торговельно-економічних відносин. Особлива увага акиентується на необхідності вдосконалення товарної структури експорту, збільшення в ньому продукції з високою часткою доданої вартості.

Ключові слова: глобалізація, індекс процвітання країн, експортно-імпортні операції, конкурентоспроможність, країни балканського регіону

Pассмотрены факторы влияния на расширение торгово-экономического сотрудничества Украины с балканскими странами. Внешнеэкономические связи оцениваются как с позиций расширения присутствия Украины на рынке Балканского региона, так из позиций стратегических намерений - усилении ее влияния на рынке ЕС. Осуществлен сравнительньий анализ состояния сочиально-экономического развития Украины и балканских государств по основным показателям. Приведены группь показателей и место Украины, каждой из балканских стран в Индексе проиветания стран (экономика, предпринимательство, государственное управление, образование, здравоохранение, безопасность, личные свободы, соичальный капитал). Исследованы тенденщии осуществления экспортно-импортных операщий между Украиной и балканскими странами. Предложень рекомендачии относительно дальнейтего развития двусторонних торгово-экономических отношений. Особое внимание акцентируется на необходимости совершенствования товарной структуры экспорта, увеличении в нем продукции с высокой долей добавленной стоимости.

Ключевые слова: глобализация, индекс процветания стран, экспортно-импортные операции, конкурентоспособность, страны балканского региона 
The factors of influence are considered on expansion of trade and economic collaboration of Ukraine with the Balkan states. External economic copulas are estimated both from positions of expansion of presence of Ukraine to the market of the Balkan region and from positions of strategic intentions - strengthening of her influence to the market of EU. The comparative analysis of socioeconomic development of Ukraine and Balkan states status is carried out on basic indexes. Groups over of indexes and place of Ukraine are brought, each of the Balkan states in Index of prosperity of countries (economy, enterprise, state administration, education, health protection, safety, personal freedoms and social capital). The tendencies of realization of export-import operations are investigational between Ukraine and Balkan countries. Recommendations are offered in relation to further development of bilateral trade and economic relations. The special attention is accented on the necessity of perfection of commodity structure of export, increase in him of products with high part of value-added.

Keywords: globalization, index of prosperity of countries, export-import operations, competitiveness, countries of the Balkan region

Вступ. Серед 212 країн світу, 3 якими Україна здійснює зовнішньоторговельні операції (2017р.), на особливу увагу заслуговують країни балканського регіону. Головний аргумент такого твердження полягає в тому, що серед повноправних членів європейської спільноти вже є Греція, Словенія, Болгарія і Хорватія. На вступ до СС претендують: Македонія, Албанія, Боснія та Герцеговина, Чорногорія і Сербія. 3 урахуванням стратегічних намірів України щодо членства в $€$, маємо виважено використати у своїх власних інтересах саме “балканський вектор”.

У цьому зв’язку нагадаємо висловлювання Г.Дж. Пальмерстона (17841865) щодо пріоритету інтересів Англії на міжнародній арені. У виступі в парламенті у 1848 р. ним було проголошено: “Тому я стверджую, що недалекоглядно вважати ту або іншу країну незмінним союзником або вічним ворогом Англії. У нас немає незмінних союзників, у нас немає вічних ворогів. Лише наші інтереси незмінні і вічні, і наш обов'язок - наслідувати їх" [1, с. 586]. Ось приклад зразкового прагматизму в зовнішній політиці, приклад жорсткого та послідовного обстоювання інтересів свого громадського класу і своєї держави. До речі, Г.Дж. Пальмерстон упродовж тривалого періоду (35 років) досить енергійно проповідував активну позицію Великобританії в іiі протиборстві з російським царським самодержавством за вплив на Балканах і в Свропі в цілому [2]. Балканські країни завжди були і залишатимуться у сфері інтересів ключових гравців на світовій політичній та економічній арені [3, с. 105-110].

Серед визначальних факторів очікуваної ефективності торговельноекономічних зв'язків з країнами балканського: географічна близькість країн; “переплетіння" в історичному розвитку; близькість мови, релігії, традицій; значна частка населення в балканських країнах має українське коріння, а в Україні чимало проживає, наприклад, греків і болгар; наявність транспортних 
комунікацій; схожість структури національних економік; ідентичність проблем у сфері реформування економіки.

При розгляді багатосторонніх аспектів міжнародного торговоекономічного співробітництва у контексті розвитку глобалізаційних та євроінтеграційних процесів досить незначним $є$ коло авторів, які предметно займаються проблематикою саме балканських країн. Серед дослідників 3 “балканського" напряму назвемо імена: І. Ангелов [4], В. Драшкович [5], В. Михайлов [6], В. Царевський [7], М. Юрчак [8]. Разом з тим, у наукових дослідженнях залишаються недостатньо розкритими проблемні питання теорії та практики економічних відносин України з державами балканського регіону.

Постановка завдання. Мета дослідження полягає в оцінці ефективності здійснення експортно-імпортних операцій, пошуку шляхів і методів їx активізації між Україною та державами балканського регіону.

Методологія дослідження. Теоретичною та методологічною основою наукового пошуку є діалектичний метод пізнання істини, принципи системного аналізу, методи статистичної обробки і узагальнення інформації, публікації структурних підрозділів $\mathrm{OOH}, \mathrm{CC}$, державної служби статистики України, дипломатичних місій, праці вітчизняних і зарубіжних авторів 3 проблем розвитку світової економіки, глобалізації, євроінтеграційних процесів, торговельно-економічного співробітництва з балканськими країнами.

Результати дослідження. Україна та балканські країни у світових рейтингах. В табл. 1 представлені дані, які дають можливість зіставити потенціал України та іiі балканських партнерів. За чисельністю населення балканські країни не входять до першої сотні світових держав (крім Греції). У сукупності потенціал ринку 9 балканських країн рівнозначний українському ринку (40, 612 млн. і 42, 481 млн. населення відповідно).

За ВВП (ПКС) Україна (49-е місце у світовому рейтингу) випереджає усі балканські країни. Що стосується показника ВВП (ПКС) на душу населення, то Україна суттєво відстає від балканських країн (113-е місце серед 185 країн світу). Близькими сусідами у рейтингу є Боснія і Герцеговина - (103-е місце), Албанія (96-е), Сербія (87-е), Македонія (85-е), Чорногорія (75-е місце). Отже, ефективність економіки, продуктивність суспільної праці у цих країнах знаходяться на досить низькому рівні.

Таблиия 1

Рейтинги балканських країн за основними показниками соціальноекономічного розвитку

\begin{tabular}{|l|c|c|c|c|c|}
\hline $\begin{array}{l}\text { Країна / } \\
\text { показники }\end{array}$ & $\begin{array}{c}\text { Населення, } \\
\text { млн. }\end{array}$ & $\begin{array}{c}\text { ВВП(ПКС), } \\
\text { \$ млрд. }\end{array}$ & $\begin{array}{c}\text { ВВП(ПКС), } \\
\text { \$ / чол. }\end{array}$ & ІЛР & $\begin{array}{c}\text { Середня } \\
\text { зарплата, } €\end{array}$ \\
\hline Болгарія & $7,202(102)$ & $137(76)$ & $19169(62)$ & $0,782(49)$ & 333 \\
\hline Греція & $10,649(84)$ & $287(55)$ & $26391(45)$ & $0,865(29)$ & 704 \\
\hline Хорватія & $4,191(127)$ & $91(83)$ & $21625(56)$ & $0,818(47)$ & 712 \\
\hline Словенія & $2,087(146)$ & $64(99)$ & $30918(38)$ & $0,880(25)$ & 1000 \\
\hline
\end{tabular}




\begin{tabular}{|l|c|c|c|c|c|}
\hline Боснія і Герц-на & $3,792(130)$ & $41(110)$ & $10550(103)$ & $0,733(85)$ & 422 \\
\hline Македонія & $2,069(147)$ & $29(128)$ & $14048(85)$ & $0,747(81)$ & 346 \\
\hline Сербія & $7,114(103)$ & $98(81)$ & $13699(87)$ & $0,771(66)$ & 436 \\
\hline Чорногорія & $0,622(168)$ & $10(153)$ & $16016(75)$ & $0,802(49)$ & 486 \\
\hline Албанія & $2,886(140)$ & $33(123)$ & $11304(96)$ & $0,733(85)$ & 370 \\
\hline Україна & $42,481(32)$ & $340(49)$ & $7987(113)$ & $0,747(81)$ & 178 \\
\hline
\end{tabular}

Примітка: Складено за доступними даними структурних підрозділів ООН

Комплексним порівняльним показником очікуваної тривалості життя, грамотності, освіти і рівня життя для країн у світі виступає Індекс людського розвитку (ІЛР). 3 низьким значенням даного показника Україна разом 3 Македонією (81-е місце у світовому рейтингу), а також з Албанією та Боснією і Герцеговиною (85-е місце) завершують першу половину світового рейтингу (усього -188 країн). Україна разом з Болгарією “лідирують” за надзвичайно чутливим для кожного громадянина показником. Йдеться про середню місячну заробітну плату. Станом на 13.05 .2016 р. Болгарія - найбідніша країна в ЄС (€333), Україна - найбідніша на європейському континенті (€178).

Одним із комбінованих показників для оцінки якості життя населення виступає Індекс процвітання країн [9]. Складається він на основі 79 показників, об'єднаних у 8 категоріях: 1) економіка; 2) підприємництво; 3) управління; 4) освіта; 5) охорона здоров'я; 6) безпека; 7) особистих свобод; 8) соціальний капітал. Саме у такій послідовності подані дані по кожній країні (табл.2).

Україна у 2015 р. зайняла 70-е місце в рейтингу процвітання, понизившись порівняно з 2014 р. на 7 позицій. Згідно з даними рейтингу, краще всього в Україні йдуть справи у сфері соціального капіталу (41-е місце). Найгірша ситуація - у сфері державного управління (118-а позиція). Україна в Індексі процвітання поступається балканським країнам-членами СС (Словенія - 29-е місце, Греція - 49-е , Болгарія - 51-е, Хорватія - 53-е), а також Чорногорії (60) та Македонії (65). Випереджає Україна Сербію (73), Албанію (83) та Боснію і Герцеговину (86). Детальніше зупинимося на двосторонніх торговельноекономічних відносинах України з балканськими державами.

Таблиия 2

Рейтинг балканських країн та України за сукупним Індексом процвітання-2015

\begin{tabular}{|l|c|c|c|c|c|c|c|c|c|}
\hline \multicolumn{1}{|c|}{ Країна } & Рейтинг & №1 & №2 & №3 & №4 & №5 & №6 & №7 & №8 \\
\hline Словенія & 25 & 58 & 25 & 33 & 11 & 27 & 14 & 25 & 40 \\
\hline Греція & 49 & 102 & 46 & 49 & 32 & 29 & 27 & 108 & 100 \\
\hline Болгарія & 51 & 799 & 43 & 81 & 44 & 48 & 42 & 96 & 67 \\
\hline Хорватія & 53 & 64 & 51 & 52 & 41 & 39 & 41 & 104 & 120 \\
\hline Чорногорія & 60 & 112 & 62 & 69 & 50 & 60 & 48 & 76 & 68 \\
\hline Македонія & 65 & 86 & 57 & 70 & 74 & 50 & 58 & 83 & 96 \\
\hline Україна & 70 & 127 & 52 & 120 & 37 & 79 & 54 & 91 & 41 \\
\hline Сербія & 73 & 121 & 82 & 77 & 45 & 55 & 64 & 59 & 107 \\
\hline Албанія & 83 & 109 & 73 & 91 & 71 & 65 & 47 & 82 & 138 \\
\hline
\end{tabular}




\begin{tabular}{|l|l|l|l|l|l|l|l|l|l|}
\hline Боснія і $\Gamma$-на & 86 & 116 & 95 & 118 & 68 & 58 & 61 & 112 & 88 \\
\hline
\end{tabular}

Примітка: Складено за [9]

Україна - Болгарія. Економіці Болгарії притаманна низька продуктивність і конкурентоспроможність на європейських і світових ринках. Істотною перешкодою для іноземних інвестицій і економічного зростання $\epsilon$ відсутність виваженої стратегії розвитку. Розмір середньої зарплати в Болгарії в 5,5 разів менше середньої зарплати в ЄС. Ї̈̈ рівень відстає й від середньої зарплати в інших Балканських країнах. Так, в Румунії вона вища на 21\%, в Македонії - на 16,6\%, в Сербії - на 35\%.

Болгарія виступає одним із головних торгівельних партнерів України на Балканах. Динаміка торговельного співробітництва за товарною структурою представлена у табл. 3. Товарообіг у 2008p. сягнув максимальної величини $\$ 1,4$ млрд. В останні роки має місце падіння обсягів товарообігу. Основні товарні групи українського експорту в Болгарію: чорні метали, вугілля та кокс, механічне обладнання, машини і механізми. У складі болгарського експорту в Україну: лікарські засоби, нафтопродукти, косметична та фармацевтична продукція, полімерні та пакувальні матеріали, тютюнова сировина.

Таблиия 3

Динаміка товарообміну між Україною і Болгарією, \$млн.

\begin{tabular}{|l|c|l|l|c|l|l|l|l|}
\hline Показники & 2001 & 2005 & 2010 & 2011 & 2012 & 2013 & 2014 & 2015 \\
\hline Товарообіг & 363,7 & 652,2 & 668,9 & 1025,1 & 849,3 & 892,3 & 788,9 & 672,7 \\
\hline Експорт & 298,5 & 543,5 & 450,9 & 755,4 & 568,8 & 591,3 & 550,6 & 419,5 \\
\hline Імпорт & 65,2 & 108,7 & 218,0 & 269,7 & 280,5 & 301,0 & 238,3 & 253,2 \\
\hline Сальдо & 233,3 & 434,8 & 232,9 & 485,7 & 288,3 & 290,3 & 312,3 & 166,4 \\
\hline
\end{tabular}

Примітка: складено у даній та наступних таблицях за [10]

За даними Держкомстату України [10] і посольства України в Болгарії [11] (у даному та інших випадках використано сайти посольств України у відповідних державах - В.Г.), у 2015 р. обсяг болгарських інвестицій (акціонерний капітал) в українську економіку зріс на $56,4 \%$ і склав $\$ 34,4$ млн. В Болгарії зареєстровано близько 400 компаній з українським капіталом, в Україні діють близько 600 підприємств за участю болгарського капіталу.

Інвестиції із Болгарії в Україну спрямовані переважно у хімічну i фармацевтичну промисловість, транспортно-логістичну сферу, харчову i переробну промисловість, торгівлю. Українські інвестиції реалізуються в Болгарії в металургійному секторі, туристичному бізнесі, будівництві та торгівлі нерухомістю. Україна входить до десятки найбільших туристичних партнерів Болгарії.

Україна - Республіка Македонія. Найтісніші торговельно-економічні зв'язки у Македонії склалися з Сербією, Чорногорією, Німеччиною, Грецією, Італією, Болгарією, Хорватією, а також з Бельгією та Іспанією. Що стосується 
культурних і торговельних зв'язків між народами, що нині населяють Україну і Македонію, то вони сягають не одне століття. Під час багаторазових відвідин цієї невеличкої держави ми від багатьох македонців чули, наприклад, про можливе прийняття обряду хрещення київськими князями Ольгою i Володимиром в Охріді, розташованого на берегу однойменного озера.

Торговельно-економічне співробітництво між Україною та Македонією вже з огляду XXI ст. здійснюється в рамках Угоди про вільну торгівлю (2001p.). Упродовж 2001-20011pp. двохсторонній товарообіг товарами збільшився в 5,3 рази і досяг у 2011 р. свого максимуму - \$229,4 млн. (табл. 4).

Таблиия 4

Динаміка товарообміну між Україною і Республікою Македонія, \$млн.

\begin{tabular}{|l|c|c|c|c|c|c|c|c|}
\hline Показники & 2001 & 2005 & 2010 & 2011 & 2012 & 2013 & 2014 & 2015 \\
\hline Товарообіг & 43,1 & 38,5 & 122,3 & 229,4 & 39,2 & 40,8 & 61,8 & 25,6 \\
\hline Експорт & 41,8 & 35,9 & 96,0 & 81,8 & 13,0 & 8,1 & 40,5 & 12,9 \\
\hline Імпорт & 1,3 & 2,6 & 26,3 & 147,6 & 26,2 & 32,7 & 21,3 & 12,7 \\
\hline Сальдо & 40,5 & 33,3 & 69,7 & $-65,8$ & $-13,2$ & $-24,6$ & 19,2 & 0,7 \\
\hline
\end{tabular}

Основу українського експорту товарів до Македонії формують чорні метали, мідь і вироби з неї, реактори ядерні, котли, машини. В структурі імпорту македонських товарів в Україну переважають: тютюн та його промислові замінники, електричні машини, фармацевтична продукція, реактори ядерні, котли, машини. На 01.01.2016 р. обсяг прямих інвестицій із Македонії в економіку України склав \$1,7 млн. Найбільше інвестицій надійшло в 1990-х та на початку 2000-х років переважно в переробну промисловість, будівельну галузь та оптову торгівлю. Успішним прикладом українсько-македонського співробітництва $є$ діяльність македонської будівельної компанії "Граніт”, яка стала переможцем міжнародного тендеру по реконструкції відрізку Стрий-Львів автомагістралі Київ-Чоп. Сума проекту склала $€ 45$ млн. Протягом 2014 р. спостерігалася тенденція з нарощування обсягу інвестицій з України в економіку Македонії. На кінець 2014 р. цей показник сягнув $€ 21,22$ млн.

Україна - Республіка Сербія. Найтісніші економічні зв'язки у Сербії склалися з Німеччиною, Італією, Росією, Румунією, Боснією і Герцеговиною (БіГ). Україна належить до 20-ти найбільших торговельних партнерів Сербії. Двостороння торгівля між країнами 32011 р. має тенденцію до зниження (табл. 5). Основними групами експорту товарів з України до Сербії залишаються руди, шлаки та зола, чорні метали, енергетичні матеріали, нафта та продукти ііі перегонки, деревина і вироби з деревини, папір та картон. Основними групами імпорту товарів із Сербії до України становили: полімерні матеріали, пластмаси, фармацевтична продукція, деревина і вироби 3 неї, реактори ядерні, котли, машини, апарати і механічні пристрої. 
Динаміка товарообміну між Україною і Республікою Сербія, \$млн.

\begin{tabular}{|l|c|c|c|c|c|c|c|c|c|c|}
\hline Показники & $\begin{array}{c}2001 \\
\text { Ю }\end{array}$ & $\begin{array}{c}2005 \\
\text { Ю }\end{array}$ & $\begin{array}{c}2006 \\
\mathrm{C}+\mathrm{Ч}\end{array}$ & $\begin{array}{c}2007 \\
\mathrm{C}+\mathrm{Ч}\end{array}$ & 2010 & 2011 & 2012 & 2013 & 2014 & 2015 \\
\hline Товарообіг & 84 & 304 & 322 & 415 & 275 & 389 & 252 & 263 & 253 & 189 \\
\hline Експорт & 61 & 251 & 250 & 349 & 199 & 274 & 125 & 122 & 112 & 106 \\
\hline Імпорт & 23 & 53 & 72 & 66 & 76 & 115 & 127 & 141 & 141 & 83 \\
\hline Сальдо & 38 & 198 & 178 & 283 & 123 & 159 & -2 & -19 & -29 & 23 \\
\hline
\end{tabular}

Примітка: складено за [11], Ю - Югославія (СФРЮ), С + Ч - Сербія і Чорногорія

Серед головних українських експортерів: “Мітал Стіл”, Полтавський ГЗК, “Запоріжсталь”, “Дніпроспецсталь”, НКМЗ, “Азовсталь”. Так, “Азовмаш” у 2010p. поставив сербському металургійному комбінату US Steel Serbia вузли вантажного обладнання для доменної печі. Станом на 01.01.2016 p. обсяг прямих інвестицій із Сербії в економіку України склав \$32,6 млн. Найбільшими інвесторами є компанії "МК Груп" i “Таркетт". Інвестиції спрямовуються, насамперед, в сільське господарство та промисловість.

Україна - Чорногорія. Чорногорія стала незалежною державою у 2006 p. Упродовж першого десятиріччя торговельно-економічних відносин між двома країнами обсяги товарообігу є незначними і коливаються в межах $\$ 1,5$ млн. (2009 р.) - \$8,7 млн. (2012 р.) - табл. 6. Динамічно зростає обсяг послуг, які надає чорногорська сторона через туризм. За кількістю туристів до Чорногорії Україна посідає 4 місце, поступаючись Росії, Сербії, Албанії.

За структурою українського експорту до Чорногорії головними торговельними позиціями є: чорні метали, продукти перегонки нафти, олія, цукор, запасні частини до машин та механізмів, одяг, електричні пристрої, освітлювальне та холодильне обладнання, целюлозні волокна. Основні товарні групи чорногорського імпорту: запасні частини автомобілів, боєприпаси та піропатрони, алкогольні напої, паперові вироби.

Таблиия 6

Динаміка товарообігу між Україною і Чорногорією, \$млн.

\begin{tabular}{|l|c|c|c|c|c|c|c|c|}
\hline Показники & 2008 & 2009 & 2010 & 2011 & 2012 & 2013 & 2014 & 2015 \\
\hline Товарообіг & 3,7 & 1,5 & 6,2 & 3,7 & 8,7 & 2,5 & 2,9 & 6,0 \\
\hline Експорт & 2,7 & 0,5 & 3,9 & 2,6 & 5,7 & 1,4 & 1,8 & 1,1 \\
\hline Імпорт & 1,0 & 1,0 & 2,3 & 1,1 & 3,0 & 1,1 & 1,1 & 4,9 \\
\hline Сальдо & 1,7 & $-0,5$ & 1,6 & 1,5 & 2,7 & 0,3 & 0,7 & $-3,8$ \\
\hline
\end{tabular}

За даними посольства України у Чорногорії, характерною особливістю двохсторонніх торговельно-економічних відносин $\epsilon$ те, їх визначають, насамперед, представники малого та середнього бізнесу. Так, підприємства "Світло-сервіс" та НВП "Гегель" забезпечили постачання та інсталяцію світового обладнання для центрального храму в м. Подгориця. Фірма 
"Монтелор" продовжує підготовку до виробництва кондитерських виробів у м. Цєтіньє. В економіку Чорногорії за останні 5 років надійшло €9,4 млн. інвестицій з України, головним чином в туризм, нерухомість та виробництво. Зростає кількість українських інвестицій, які надходять 3 третіх країн. Зокрема, українсько-кіпрська компанія Politropus Alternative придбала частину виробництв комбінату алюмінію м. Подгориця (на $\$ 300$ тис.). В планах власника компанії Р. Данькевича: інвестувати в розвиток ще близько $\$ 50$ млн.

Серед чинників, що потенційно можуть сприяти розвитку двосторонніх економічних зв'язків, співробітники посольства України в Чорногорії відносять: безвізовий режим; розвинуту логістику; існування економічних зон 3 пільговим оподаткуванням. До несприятливих чинників відносять: загальне зменшення обсягів зовнішньої торгівлі України; недооцінка українським бізнесом потенційних можливостей ринку Чорногорії; неучасть українських підприємств у виставках в країні перебування.

Україна - Боснія і Герцеговина. Економіка БіГ посідає одне з останніх місць в Європі за рівнем ВВП. Географічний розподіл зовнішньої торгівлі БіГ (2014 р.) виглядає наступним чином: країни $€ \mathrm{CC}(64,0 \%$, Росія $(5,5 \%)$, Китай $(5,5 \%)$, Туреччина $(3,3 \%)$, країни Америки $(3,3 \%)$, африканські країни $(0,8 \%)$. Важливими торговельними партнерами країни залишаються колишні республіки СФРЮ, насамперед, Хорватія, Сербія і Словенія. Що стосується економічних відносин між Україною та БіГ, то обсяги товарообігу $\epsilon$ незначними (табл.7).

Максимум за показником товарообігу між двома країнами мав місце у 2008 р. - \$112,0 млн. 32009 р. і донині активність у здійсненні експортноімпортних операцій помітно знижується. Домінуючими статтями експорту 3 України до БіГ традиційно залишаються вироби з чорних та кольорових металів, продукція машинобудування тощо. У структурі імпорту з БіГ до України переважає фармацевтична продукція, нафта, продукти ії перегонки та вугілля , товари хімічної промисловості.

Таблиия 7

Динаміка товарообігу між Україною та Боснією і Герцеговиною, \$млн.

\begin{tabular}{|l|c|c|c|c|c|c|c|c|}
\hline Показники & 2001 & 2005 & 2010 & 2011 & 2012 & 2013 & 2014 & 2015 \\
\hline Товарообіг & 10,6 & 15,1 & 22,5 & 66,1 & 45,5 & 33,7 & 40,2 & 17,1 \\
\hline Експорт & 10,5 & 15,1 & 14,9 & 45,5 & 31,4 & 15,0 & 10,8 & 7,4 \\
\hline Імпорт & 0,1 & - & 7,6 & 20,6 & 14,0 & 18,7 & 29,3 & 9,7 \\
\hline Сальдо & 10,4 & 15,1 & 7,3 & 24,9 & 17,4 & $-3,7$ & $-18,5$ & $-2,3$ \\
\hline
\end{tabular}

Україна - Республіка Словенія. Словенія - розвинена держава, 3 ефективною та стабільною економікою. ВВП на душу населення складає 88\% від середнього значення по 28 країнам СС. Словенія має освічену робочу силу, розвинену інфраструктуру. Вона знаходиться на перехресті важливих транспортних шляхів. Зовнішня торгівля орієнтована, передусім, на Німеччину, 
Австрію, Італію, Францію та інші країни СС (2/3 торгових зв'язків). Обсяги зовнішньої торгівлі складають близько 120\% від ВВП (експорт + імпорт).

Серед країн колишньої Югославії в 2008 р. Словенія вийшла на перше місце за обсягом товарообігу з Україною. Максимального значення товарообіг досяг у 2011 р. - \$365,6 млн. (табл.8). У подальшому обсяги взаємної торгівлі мають тенденцію до зниження. Характерним є від'ємне для України сальдо торгівлі товарами та послугами зі Словенією.

Таблиия 8

Динаміка товарообміну між Україною і Республікою Словенія, \$млн.

\begin{tabular}{|l|c|c|c|c|c|c|c|c|}
\hline Показники & 2001 & 2005 & 2010 & 2011 & 2012 & 2013 & 2014 & 2015 \\
\hline Товарообіг & 57,3 & 158,0 & 224,2 & 365,6 & 261,4 & 300,5 & 219,6 & 145,2 \\
\hline Експорт & 10,9 & 32,5 & 11,6 & 10,7 & 10,4 & 13,0 & 16,0 & 16,3 \\
\hline Імпорт & 46,4 & 125,5 & 212,6 & 254,9 & 251,0 & 287,5 & 203,6 & 128,9 \\
\hline Сальдо & $-35,5$ & $-93,0$ & $-201,0$ & $-244,2$ & $-240,6$ & $-274,5$ & $-187,6$ & $-112,6$ \\
\hline
\end{tabular}

Головні товарні позиції в структурі українського експорту: чорні метали та вироби з них, полікарбонові кислоти, деревина та вироби з неї. Основну частку українського імпорту зі Словенії складають: ліки та медичні препарати, побутова техніка, телефонні станції. Станом на 01.01.2016 р. обсяг прямих інвестиції зі Словенії в економіку України склали \$52,7 млн.

Україна - Хорватія. Хорватія вступила в СС у 2013 р., ставши 28-м його членом. Лише у 2015 р. країна вийшла із рецесії. 16,3\% економічно активних хорватів - безробітні. Хорватія демонструє третій найгірший показник в СС після Греції та Іспанії. Співвідношення державного боргу до ВВП - 86,7\%. Хорватія залишається єдиною країною $Є С$, де купівельна спроможність на сьогодні нижче, ніж у 2008 р. Після Болгарії Хорватія має найслабкішу економіку в СС. Поліпшити ситуацію в країні повинні структурні реформи, які повільно реалізуються з-за політичних проблем.

Що стосується товарообігу між Україною та Хорватією упродовж 20012012 pр., то він мав тенденцію до зростання (табл. 9). 32012 р. даний показник почав помітно скорочуватися. У структурі товарного експорту з України переважають: чорні метали та вироби з них, деревина та вироби з неї, вироби зі скла. Структура товарного імпорту до України характеризувалася переважанням обладнання для атомної енергетики, фармацевтичної продукції, полімерних матеріалів, ефірних олій.

Таблиия 9

Динаміка товарообміну між Україною і Хорватією, \$млн.

\begin{tabular}{|l|c|c|c|c|c|c|c|c|}
\hline Показники & 2001 & 2005 & 2010 & 2011 & 2012 & 2013 & 2014 & 2015 \\
\hline Товарообіг & 36,7 & 80,0 & 83,6 & 104,4 & 109,4 & 80,0 & 87,1 & 41,3 \\
\hline Експорт & 29,8 & 60,6 & 33,4 & 51,5 & 40,2 & 43,8 & 39,2 & 26,1 \\
\hline Імпорт & 6,9 & 19,4 & 50,2 & 52,9 & 69,2 & 36,2 & 47,9 & 15,2 \\
\hline Сальдо & 22,9 & 41,2 & $-16,8$ & $-1,4$ & $-29,1$ & 6,9 & $-8,7$ & 10,9 \\
\hline
\end{tabular}


Україна - Республіка Греція. У результаті тривалої економічної кризи 2008-2013 рр., Греція уперше в практиці світових фінансових агентств втратила статус розвиненої країни. Вона повернулася до категорії країн, що розвиваються. Економічна криза триває у Греції й нині. В країні - слабкі показники експорту, рекордне безробіття, низька купівельна спроможність населення. Серед основних торговельних партнерів: Італія, Німеччина, США, Франція, Велика Британія.

Торговельно-економічні відносини між Україною і Грецією розвиваються досить стабільно (табл. 10). Аналіз складових українського експорту до Греції виявив динаміку його диверсифікації за окремими товарними позиціями. Зокрема, йдеться про зростання експорту суден, зернових культур, виробів із шкіри, друкованої продукції, паперу та картону.

Таблиия 10

Динаміка товарообігу між Україною та Грецією, \$млн.

\begin{tabular}{|l|c|c|c|c|c|c|c|c|}
\hline Показники & 2001 & 2005 & 2010 & 2011 & 2012 & 2013 & 2014 & 2015 \\
\hline Товарообіг & 177,3 & 205,5 & 268,2 & 419,9 & 401,3 & 505,4 & 509,7 & 392,4 \\
\hline Експорт & 138,4 & 137,8 & 164,1 & 291,2 & 209,3 & 227,9 & 201,2 & 153,8 \\
\hline Імпорт & 38,9 & 67,7 & 104,1 & 128,7 & 192,0 & 277,5 & 308,5 & 238,6 \\
\hline Сальдо & 99,5 & 70,1 & 60,0 & 162,5 & 17,2 & $-49,6$ & $-107,3$ & $-84,8$ \\
\hline
\end{tabular}

Негативний внесок у скорочення окремих українських експортних складових завдано російською агресією на сході України. Скоротилися обсяги послуг, наданих Україною грецьким споживачам, оскільки значна їх частина припадала на анексований Крим. Зокрема, це стосується обслуговування грецьких суден та екіпажів. Греція займає 12 місце $(0,7 \%$ від загального обсягу) за обсягами прямих інвестицій в Україну серед країн Європи. Найбільш привабливою сферою для інвестицій залишаються фінансова діяльність та будівництво. На українському ринку функціонують грецькі банки - "Піреус Банк”, “EFG Євробанк Ергасіас”, „Альфа Банк”, „Марфін Егнатіа Банк”.

Україна - Республіка Албанія. Статус кандидата в члени ЄС Албанія отримала в 2014 р. Економіка країни - одна із швидко розвиваючих у світі. Фахівці Fitch Ratings прогнозують, що у 2017 р. темп зростання ВВП Країни орлів досягне відмітки в 3,6\%. Інфляція в Албанії в 2016 р. знаходиться на рівні $2,9 \%$. Албанія входить в десятку найбезпечніших країн світу з населенням до 5 млн. Албанія попереду усіх східноєвропейських країн за рівнем життя для пенсіонерів. Завдяки своїй економічній моделі, спрямованій на зниження податків, Албанія притягує все більше іноземних інвесторів. На збереження стабільності політичного, економічного і ділового середовища може негативно вплинути наплив іммігрантів.

Географічний розподіл зовнішньої торгівлі Албанії (2014р.) виглядає наступним чином: країни $Є \mathrm{C}-66,0 \%$, Туреччина $-6,1 \%$, Китай $-6,1 \%$, Росія - 
1,5\%, країни Америки - 3,8\%, країни Африки - 1,5\%. Україна виступає також одним із важливих торговельних партнерів Албанії. Найбільш вдалим для українських експортерів був 2007 р. Обсяги поставок склали \$104,0 млн. Надалі обсяги товарообігу мають тенденцію до зниження (табл. 11). Відбулося певне зростання албанського імпорту (чорні метали, пластмаси, полімерні матеріали). Має місце відсутність суттєвих коливань обсягів основних складових українського експорту: добрива, чорні метали та жири й олії тваринного або рослинного походження.

Таблиия 11

Динаміка товарообміну між Україною та Республікою Албанія, \$млн.

\begin{tabular}{|l|c|c|c|c|c|c|c|c|}
\hline Показники & 2001 & 2005 & 2010 & 2011 & 2012 & 2013 & 2014 & 2015 \\
\hline Товарообіг & 12,7 & 56,6 & 49,0 & 60,4 & 55,6 & 33,2 & 25,8 & 27,8 \\
\hline Експорт & 12,2 & 55,5 & 48,3 & 58,5 & 54,2 & 31,8 & 24,5 & 24,9 \\
\hline Імпорт & 0,5 & 1,1 & 0,7 & 1,9 & 1,4 & 1,4 & 1,3 & 2,9 \\
\hline Сальдо & 11,7 & 54,4 & 47,6 & 56,6 & 52,8 & 30,4 & 23,2 & 22,0 \\
\hline
\end{tabular}

Серед 30 українських підприємств, які співпрацюють 3 Албанією, за обсягами торгівлі можна виділити: ВАТ “Лукойл - Україна”, АТ “Чернівецький машинобудівний завод ”, ВАТ „Міттал Стіл - Криворіжсталь, “Запоріжсталь”, BAT "Стальканат”. На українському ринку діє близько 20 албанських компаній, які зайняті торгівлею чорними металами і зерновими.

Висновки. Розвинена країна - це високий рівень моралі в суспільстві, компетентність і відповідальність влади, потужний промисловий потенціал і розвинене сільське господарство, висока якість життя i чисте довкілля. Розвинена країна - це ефективне управління інноваційним розвитком. Розвинена країна - це достойне місце у міжнародному розподілі праці. $Є$ Закон України "Про зовнішньоекономічну діяльність" [12], інші директивні документи. У них вказано: диверсифікувати, оптимізувати, сприяти, розробити, визначити, виробити, зосередити, використати і т.д. На їх продовження має прийти: зробити, втілити у життя. Ключовою залишається проблема лідерства. Лідерство не в деклараціях, а в їх реалізації. Тоді ми не відставатимемо від світу, від Європи, а випереджатимемо події. Пріоритети України у глобалізованому світі - у кожному його куточку. Особливим таким куточком $\epsilon$ Балканський регіон, зважаючи на історичний, мовний, релігійний i ... торговельно-економічний фактори. 


\section{Література:}

1. Bourne K. Palmerstone; the Early Years 1784-1841. - London, Allen Lane, 1982. - 749 p.

2. Виноградов В.Н. Великобритания и Балканы: от Венского конгресса до Крымской войны. Монография / В. Н. Виноградов. - М.: Наука, 1985. - 336 с.

3. Герасимчук В. Г. Балканські країни в структурі зовнішньої торгівлі України / В. Г. Герасимчук // Економічний вісник НТУУ “КПІ” : збірник наукових праць. - 2011. - № 8. C. $105-110$.

4. Ангелов И. Перспективы экономического сближения Болгарии с Евросоюзом / И. Ангелов // Проблемы теории и практики управления. - 2003. - т. №5. - С. 34-40.

5. Драшкович В. Экономические отношения Сербии и Черногории: роль Евросоюза / В. Драшкович // Мировая экономика и международные отношения: МЭМО, 2003. - т. №5. - C.105-108.

6. Михайлов В.Т. Балканы как пространство проблемной наднациональной идентичности / В. Т. Михайлов [Электронный ресурс]. - Режим доступа: http://www.perspektivy.info/rus/gos/balkany_kak_prostranstvo_

problemnoj_nadnacionalnoj_identichnosti_2014-02-21.htm.

7. Царевский В. Механизм и экономические последствия либерализации торговли в Болгарии / Владимир Царевский // Проблемы теории и практики управления. - 2004. - т. № 5. - С. 57-64.

8. Юрчак М. Потенціал впливу балканських держав на формування політики СС щодо України / М. Юрчак // Україна-Свропа-Світ : міжнародний збірник наукових праць. Тернопіль : ТНПУ, 2014. - Вип. 13. - С. 163-170.

9. Рейтинг стран мира по уровню процветания. Гуманитарная энциклопедия [Электронный pecypc]// Центр гуманитарных технологий, 2006-2016. URL: http://gtmarket.ru/ratings/legatum-prosperity-index/info.

10. Статистична інформація. Зовнішньоекономічна діяльність. Географічна структура зовнішньої торгівлі товарами. Державна служба статистики України [Електронний ресурс]. Режим доступу: www.ukrstat.gov.ua.

11. Посольство України в Болгарії. Стан торговельно-економічних відносин та інвестиційної діяльності між Україною та Болгарію [Електронний ресурс] - Режим доступу: http://www.mfa.gov.ua/bulgaria/ua/16937.htm.

12. Закон України “Про зовнішньоекономічну діяльність” від 16.04.1991 № 959-XII. Офіційний сайт ВРУ. - Режим доступу: htpp://zakon3. rada.gov.ua. 